\title{
中山間地域等直接支払制度の变遷と効果に関する考察
}

林謙介（神戸大学大学院農学研究科）

\section{Changes in and Effects of Direct Payments for Hilly and Mountainous Areas on Farming Practices}

\author{
Kensuke Hayashi (Graduate School of Kobe University)
}

This paper aims to clarify the effects of changes in Direct Payments for Hilly and Mountainous Areas (DPHMA) on farmer organizations in target areas. DPHMA began in 2000 and has changed every 5 years. This study recognizes 3 dimensions of change in DPHMA. The first dimension is "enlargement," the second, "thinking strategically," and the third, "strengthening cooperation." Farmer organizations have adapted to these changes.

Enlargement of each farmer organization's farm-

\section{1. はじめに}

中山間地域に打ける多面的機能（農産物供給及び 洪水防止・水源涵養・景観形成等の公益的機能）は, 農業生産活動等（農用地に打辇る耕作，農用地の維 持・管理，水路・農道等の維持・管理）の実施を通 して発揮される。 しかしながら, 中山間地域では高 齢化の進行や人口流出による農村の「空洞化」が深 刻化して扔り 1)，また平地と比較して生産性が低い といら農業生産上の不利性を抱えている.これらは, 中山間地域に打ける農業生産活動等を維持していく 上で障害となるものである。

そこで 2000 年度から, 平地との経済的な格差を是 正し，それを通して多面的機能を確保することを目 的として,「中山間地域等直接支払制度」(以下，「中 山間直払制度」）が施行された，本制度に沶いて担 い手たる農業者等は, 対象農用地に抢兴営農計画 を定めた「集落協定」を締結し，それに基づき 5 年 間以上農業生産活動等を行うことを条件に交付金を 受領することができる ${ }^{2)}$. 対象農用地は一般に傾斜 等の条件を満たす必要があるが，これらを満たさな くても特に不利であると認められる時には地方の裁 量で制度の対象にすることができる. ing area was observed by analyzing the data statistically; small farmer organizations preferred to unite and thus become bigger.

In the case of the F district in Shimane prefecture, two villages established one farmer organization as an extension of a farmer cooperation program in 2010. Their future master plan includes securing, developing, and make good use of human resources. It is notable that some farming lands that were about to be abandoned found a new lease of life.

本制度は農業者の所得確保に関して，日本農政史 上初めて農業者への直接支払いといら手法をとった 政策であり，その効果が未知数であることから，5 年ごとに第三者機関による評価を行い，中山間地域 の農業を取り巻く環境の変化も勘案しながら制度全 体を見直すこととされた。そのため 2 度目の見直し の後, 2010 年度からは第 3 期対策が実施されている. 第 1 期・第 2 期対策の理論的・実証的な分析は多数 行われているが，第 3 期対策までを含めた分析は多 くない3.

そこで本研究では，中山間直払制度の第 3 期対策 までの変遷を整理しつつ, 同制度が生産現場に与え た効果を検証することを課題とする。 これに接近す るため, 第一に各期対策の制度变化の内容を整理し, 第二に各期の中山間直払制度に取り組む組織の变化 を諸統計から明らかにする。そして第三に中山間直 払制度に取り組省事例集落の分析から中山間直払制 度の効果の実態を明らかにする。

\section{2. 中山間直払制度の変遷}

中山間直払制度は，施行以来現在に至るまでに 2 度の見直しが行われてきた，本研究では同制度の変 
化の方向として「拡大志向」「ビジョンの長期化」「集 落間連携の強化」を見出した．本節ではこれらの方 向を構成する要素について検討することとする.

まず，第一の方向である「拡大志向」が意味する のは，集落協定が対象とする農用地の拡大を進める ことである. この方向は，第 2 期対策にお打る集落 協定の各種締結要件の緩和といら点において確認で きる(表 2). 集落協定の締結単位が「地域の実情 に即した適切な範囲」となったことで, 地理的に離 れていても文化的・歴史的経緯等を勘案して集落協 定を一つにすることができるようになった ${ }^{4)}$ また， 営農上の一体性を満たすための条件が緩和されたこ とで, 締結時点では低いレベルでの農用地保全活動 しか行われていない農用地であっても営農上一体性 があるとすることができ, 対象農用地面積の拡大に つながる。

次に，第二の方向である「ビジョンの長期化」が 意味するのは, 集落協定に基づく活動を, より長期 的な視点を重視したものにすることである. この方 向は次の 5 点に沶いて確認できる. 1 点目は, 第 2 期対策に打ける「法人設立加算」の創設である。こ れは，新たに特定農業法人・農業生産法人を設立し た場合に，その対象面積に応じて交付額を加算する ものである，農業経営を法人化することによって，
経営面・税制面での様々なメリットを享受すること ができ，長期的な経営の安定につながると考光られ る. 2 点目は，第 2 期対策に打任る集落マスタープ ランの義務化・明確化である. 集落マスタープラン は，第 1 期対策に打いては集落の将来像を示すだけ のものとされ，作成も任意であったが，第 2 期対策 に打いて作成が義務化された。ささらに将来像を実現 するための活動方策及び協定期間，5年間の活動工 程表の作成が取り入れられたことで集落協定締結の ハードルとなったが，一方で将来像実現における不 確実性を低減することにより，長期的な視点に立つ ことが可能になったと考光られる，以上の 2 点は協 定組織に対して発展的な活動の道を示寸ものである と考光られる。 3 点目は，第 3 期対策に打怕集落 協定の締結要件の緩和である. 第 3 期対策に移行す るにあたり, 一団の農用地の構成要件から営農上の 一体性が削除された。

これは高齢化の進行に伴い単一集落での協定締結 が困難になることから，複数集落による協定の締結 が促進されるものと考えてのことである。また営農 上の一体性に代わり，農用地保全に向けた共同取組 活動が構成要件となったが，これは営農上の一体性 を包含する概念であり，集落協定の締結を容易に寸 るものであると考光られる４４点目は，第 3 期対策

\section{表 1. 中山間直払制度の変化の方向とその類型}

\begin{tabular}{l|l|l}
\hline \hline & 第 1 期から第 2 期への変化 & 第 2 期から第 3 期への変化 \\
\hline 拡大志向 & 集落協定締結要件の緩和 & \\
\hline \multirow{3}{*}{ ビジョンの長期化 } & 法人設立加算の創設 & 集落協定締結要件の緩和 \\
\cline { 2 - 3 } & 集落マスタープランの義務・明確化 & 小規模・高齢化集落支援加算の創設 \\
\cline { 3 - 3 } & & 集団的サポート型の創設 \\
\hline \multirow{2}{*}{ 集落間連携の強化 } & & 小規模・高齢化集落支援加算の創設 \\
\cline { 2 - 3 } & & 集落連携促進加算の創設 \\
\hline
\end{tabular}

注 :『中山間地域等直接支払交付金実施要領』『中山間地域等直接支払交付金実施要領の運用』ょり作成

表 2. 集落協定の締結要件の変化

\begin{tabular}{|c|c|c|c|}
\hline & 第 1 期 & 第 2 期 & 第 3 期 \\
\hline 締結単位 & （複数の）一団の農用地 & \multicolumn{2}{|c|}{ 地域の実情に即した適切な範囲 } \\
\hline 一団の農用地 & \multicolumn{2}{|c|}{$\begin{array}{l}\text { 農用地面積が } 1 \text { ha 以上の団地又は営農上の一体 } \\
\text { 性を有する複数の団地の合計面積が } 1 \text { ha 以上の } \\
\text { もの }\end{array}$} & $\begin{array}{l}\text { 農用地面積が } 1 \text { ha 以上の団地又は農用地の } \\
\text { 保全に向けた共同取組活動が行われる複数 } \\
\text { の団地の合計面積が } 1 \text { ha 以上のもの }\end{array}$ \\
\hline 営農上の一体性 & \multicolumn{2}{|c|}{$\begin{array}{l}\text { 一団の農用地を構成するすべての団地が, } 3 つ （ \text { 第 } \\
2 \text { 期は } 4 \text { つ) の条件のいずれかを満たす場合 }\end{array}$} & （廃止） \\
\hline
\end{tabular}

注 :『中山間地域等直接支払交付金実施要領』『中山間地域等直接支払交付金実施要領の運用』ょり作成 
に抢ける小規模・高齢化集落支援加算の創設である. これは，小規模・高齢化集落 6）の範囲を取り込ん で集落協定を締結した場合に交付金を加算するもの である，小規模・高齢化集落は現状のままでは農業 生産活動等を続けられなくなる集落であり，近隣の 余力のある集落がこれをサポートすることで，短期 間での荒廃を防止することができると考兄られる. 5 点目は，第 3 期対策に打忊る農業生産活動等の体 制整備の類型としての「集団的サポート型」（以下， $\lceil\mathrm{C}$ 要件」）の創設である. 体制整備は第 2 期対策以 降に扎いて第 1 期と同額の交付金を受領するための 必須要件とされ，不可能な場合には交付額が 2 割減 額されることとなった． C 要件は高齢化等で耕作の 継続が困難となった場合に，集落全体でこれをカ バーする体制を作るものであり，耕作放棄の発生を 抑制することができると考光られる. 以上の 3 点は, 協定活動が困難, あるいは協定未締結である集落に 対するセーフティネットの役割を果たするのである と考觉らる。.

そして，第三の方向である「集落間連携の強化」 が意味するのは, 既存の集落営農の範囲を超えて連 携を強化することである. この方向は次の 2 点にお いて確認できる. 1 点目は，小規模・高齢化加算の 創設である. 第 3 期以前にも複数集落による連携の 事例は存在したが，集落間の関係は対等なものとさ れてきた，本加算により，支援・被支援といら非対 等な関係での連携が促進されるものと考兄られる. 2 点目は第 3 期対策に打忊る集落連携促進加算の創 設である.これは，人・農地プランの作成を契機に 協定未締結集落を含めて集落協定を締結した場合に 交付金を加算するものである. 2013 年度からの導入 であり交付単価等が明らかではないため効果は未知 数だが, 人・農地プランに位置づけられた中心的担 い手を支える役割で協力関係を構築することが可能 であると考觉られる。これら 2 点は, 集落間連携に より協定未締結集落を救済する性質のものである.

以上，本研究が導出した中山間直払制度の変化の 3 つの方向を確認した. 同時に, 第 1 期から第 2 期 への変化は発展的活動への道を示すもの, 第 2 期か ら第 3 期への変化は協定活動レベルが低いか協定未 締結である集落を救済する性質のものであることも 確認できた，次節以降に扣いて，これらの変化が生 産現場に与えた効果について検証していく.

\section{3. 制度変化の生産現場への効果一諸統計より一}

本節では，前節で挙げた中山間直払制度の変化が 生産現場に与えた効果を，都府県の統計データを用 いて検証する。

図 1 は，都府県に打竹落協定の総締結数，農 用地の総面積及び集落協定 1 つあたりの農用地面積 （以下「平均面積」）の変化を示したものである. こ こからは以下の 2 点が分かる. 1 点目は, 制度見直 乙年度に扣いて総面積と総締結数は共に減少してい るが，前者の減少が後者と比較して相対的に小さい ことである．ここから，集落協定の統合が進んでい ることが示唆されるが, これは制度変化に打ける「集 落間連携の強化」の方向に生産現場が適応した結果 であると考兄られる。これについて高岸ら［5］は， 第 1 期から第 2 期にかけて，集落内に複数存在した 小規模な集落協定が統合したが，一方で集落の範囲 を超えた協定の統合はわずかであった，と述べてい る. 2 点目は，制度の実施期間を通して総面積が増 加し，総締結数が減少してきた結果，平均面積が増 加してきたことである。これは「拡大志向」での制 度変化に適応した現場の変化であると考兄られる.

また，対象農用地の集中度を表すジ二係数は，制

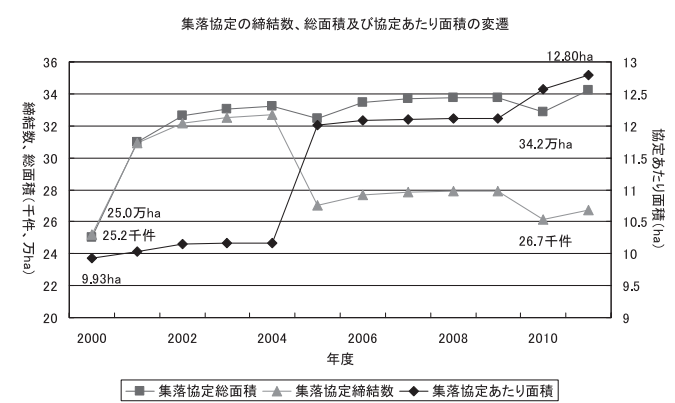

図 1. 集落協定の総締結数, 総面積及び協定あたり 面積の变遷

注 :『中山間地域等直接支払制度の実施状況』より作成

表 3. 農用地の集中度の変遷

\begin{tabular}{c|c}
\hline \hline & 各期に打ける農用地の集中度 \\
\hline 第 1 期 & 0.5573 \\
第 2 期 & 0.5497 \\
第 3 期 & 0.5443 \\
\hline
\end{tabular}

注：1）『中山間地域等直接支払制度の実施状況』より作成

2）各年度における Quasi-Gini coefficient を算出し，対 策期ごとに平均值をとった。 
度施行以来各期を通じてわずかながら低下してきて いる．これは平均面積が平準化してきているという ことであり, 平均面積の増加とあわせて考光ると, 小規模な集落協定の統合により，面積規模に扔いて 上位と下位の格差がなくなってきているものと考光 られる。

\section{4. 制度変化の生産現場への効果一島根県・F 地区 の事例より一}

本節においては，前節までの考察を踏ま兄つつ， 中山間直払制度に取り組む事例地区に扮ける制度の 効果を検証することとする.

本研究に扮いて扱う $\mathrm{F}$ 地区は島根県大田市の南 西端, 大田市・江津市・邑智郡川本町の境界線が交 わるところに位置している（図2）。1 889 年の町村 制施行以来 2 度の市町村合併を経た結果 3 市町のど の中心部からも遠くなった. また地区内に公共交通 機関がなく，冬季には豪雪になるなど，生活面・生 産面に扮いて大きな不利性を抱えている。 それにも 拘らず，中山間直払制度の第 3 期対策での変化にい ち早く適応して小規模・高齢化集落支援加算に取り 組んでいる. 同加算は全国の集落協定の 1\%程度で しか取り組ま机て扮らず，この点で $\mathrm{F}$ 地区の事例 は先進的であるとい觉る。

F 地区に打いては，2つの集落（A，B）が一体と なって集落協定を締結している，それぞれの集落の 概要は表 4 の通りである.

両集落は第 1 期に打いては個別に制度に参加して いた。しかしながら第 2 期対策に移行する際に，A 集落では農業生産活動等の体制整備が出来ずに交付 単価が 2 割削減され，B 集落は事業を管理すること ができる人がいなくなり，また高齢化により離農す る人が増えるなど営農の維持が困難になったことに より制度から離脱することとなった。 そのため $\mathrm{B}$ 集落の区域では， A 集落が耕作放棄地再生利用緊急 対策事業により耕作放棄地の再生・土壌改良・営農 定着を行い，そ机により助成を受けた。また耕作者 がいなくなった農用地では，A 集落に居住する血縁 者が耕作を請け負っていた。

その後第 3 期対策において小規模 ・高齢化集落支 援加算が創設されたのを契機に A 集落が B 集落の 区域を取り込んで集落協定を締結した。气の際B 集落内の農用地について C 要件を取り入れること

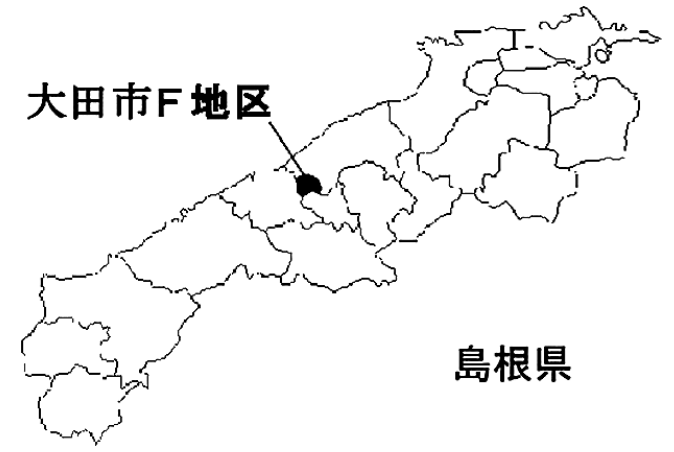

図 2. $\mathrm{F}$ 地区の位置

資料 : http://aoki2.si.gunma-u.ac.jp/map/map.html（閲覧日： 2012 年 10 月 8 日）より作成

により農業生産活動等の体制整備を行って, 交付単 価を標準単価に戻している。しかしながら 2011 年 度にはA 集落自身も小規模・高齢化集落の認定を 受け，これにより集落協定の対象農用地全てが小規 模・高齢化集落支援加算の対象となった結果，交付 金額が大幅に増加している.

$\mathrm{F}$ 地区では集落マスタープランとして農用地利用 改善組合の設立と受け血としての体制整備・個人担 い手農家の育成支援，集落営農の促進・近隣集落々 の組織的協調や連携の可能性・年間就農が可能な機 会と人材確保，及び労働条件の整備を謳っている. これらは組織的な営農体制を強固にすると共に戦略 的な見地から人的資源を配分するための計画であ り，長期的な見通しを明確にするものであると考光 られる。

$\mathrm{A}$ 集落が $\mathrm{B}$ 集落内の農用地を出作により取り込 又経営規模を拡大したのは，小規模・高齢化集落支 援加算及びC 要件の創設を契機としているが，そ の本質は第 2 期に打ける各種耕作放棄地対策及び血 縁に基づく耕作請負の維持・強化である。すなわち, 制度変化は契機であり，本質をなすのはそれまでに 構築された関係・実績であるということが分かる.

表 4. A ・ B 集落の概要

\begin{tabular}{c|c|c}
\hline \hline & $\mathrm{A}$ 集落 & $\mathrm{B}$ 集落 \\
\hline 集落内戸数 & 25 & 14 \\
\hline 農家戸数 & 20 & 2 \\
\hline 水田面積 $(\mathrm{ha})$ & $18.2(2.7)$ & 2.2 \\
\hline
\end{tabular}

注：聞き取りにより作成

注 1) 水田面積の括弧内の数值は, 急傾斜水田（傾斜が 20 分の 1 以上である水田）の面積である. 
表 5. 中山間直払制度に関連した $\mathrm{F}$ 地区の動き

\begin{tabular}{l|l|l|l}
\hline \hline 時期 & 年度 & A 集落 & B 集落 \\
\hline 第 1 期 & 2000 & 制度に参加（交付額 : A 集落約 240 万円） \\
\hline 第 2 期 & 2005 & 交付単価が 8 割に（交付額 : 約 140 万円） & 制度から離脱 \\
\hline \multirow{2}{*}{ 第 3 期 } & \multirow{2}{*}{2010} & 交付単価が標準単価に（交付額 : 約 190 万円） & 小規模・高齢化集落として制度に参加 \\
\cline { 2 - 4 } & F 地区マスタープランの作成 & 出作によりキャベッ作付け C 要件の取り入れ \\
\cline { 2 - 4 } & 2011 & 小規模・高齢化集落に認定（交付額: 約 260 万円） & 出作によりキャベッ・エゴマ作付け \\
\hline
\end{tabular}

注：聞き取りにより作成

な拉，出作地に打ける作付品目については，大田市 が産地助成金の対象としているキャベッ及びエゴマ の栽培に取り組んでいる.

F 地区に打汀る集落協定は, 制度変化に適応して そのあり方を変化させてきた。すなわち，まず「拡 大志向」の方向での制度変化に対しては，B 集落内 の農用地を取り込及面積を拡大することで対応し た. 次に「ビジョンの長期化」の方向での制度変化 に対しては, 戦略的な組織営農計画としての集落マ スタープランを作成すること及び B 集落内の農用 地に対する $\mathrm{C}$ 要件の取り入れにより対応した。 そ して「集落間連携の強化」の方向での制度変化に対 しては，集落協定を一本化し第 2 期に打ける耕作放 棄地対策及び出作を強化することで対応した．これ らの変化を通して, B 集落内の農用地は荒廃化を免 れることができた，また大きな資金的裏づけを得る ことにより，今後事業を拡充させるための基盤とな ることが考觉られる.

一方で F 地区が抱える問題も明らかになった. 第一に，地区内では高齢化が進行しているにも拘ら ず，立地条件の悪さから新規担い手の確保が困難で あり,担い手の世代交代が進んでいないことである. これについては，単独での集落維持が困難であると の視点に立って, 近隣集落との協調・連携を進めて いくしかないとの意見がある．第二に，A 集落の住 民から旧井田村の 3 分の 1 から半分程度を対象とす る大規模な集落営農の設立を望む声があるにも拘ら ず，現状では取組が停滞していることである。これ については，行政・集落双方に既存の集落の範囲を 超えることに対する心理的な抵抗感があり, 話し合 いを進めることに消極的になっているからではない かとの見解が出されている。 また，集落営農を維持 していくための人材が不足していることも, 取組が 停滞している原因となっている。 そして第三に，人
手が不足している現状が打破されなければ，A 集落 から B 集落に労働力を振り向けることが不可能と なってしまらことである。

\section{5. おわりに}

本研究では，中山間直払制度の変化及びそれが生 産現場に与える効果について，「拡大志向」「ビジョ ンの長期化」「集落間連携の強化」といら制度変化 の3つの方向を提示し，それぞれに対応する生産現 場の変化を諸統計ならびに事例の分析を通して明ら かにした。その結果, 統計レベルでは「拡大志向」「集 落間連携の強化」に対応した平均面積の拡大・集落 協定の統合が示唆された。 また，事例集落の分析か らは，小規模・高齢化集落支援加算により過去の取 組・集落間関係を強化・緊密化させ農用地の荒廃化 を防止したこと，C要件の導入により農業生産活動 等の体制整備を行った結果今後の取り組及拡充のた めの大きな資金的裏づけを得たこと，集落マスター プランにより明確で戦略的な計画を作成することが できたことが明らかになった，以上より中山間直払 制度は，その变化を通して長期的な中山間地域農業 の維持により大きな貢献をする制度となってきてい るといえる。一方で事例集落の分析からは，世代交 代及び集落の心理的な閉鎖性といら経済的でない問 題に対する解決策の欠如が制度の課題として示唆さ れたが，これについては他の政策との連携により解 決可能であると考光る．な打具体的な解決策の提示 については今後の課題としたい.

注 1）小田切 [1]［2] は，特に西日本に执いて「人の空 洞化」「土地の空洞化」「ムラの空洞化」が進行し てきたとし，これらの根底には「誇りの空洞化 があると述べている。

2）認定農業者等については，「個別協定」により同様 の条件で交付金を受領することができるが，本稿 
では扱わない。

3）例として山浦 [3] がある.

4）例として福与 [4] がある.

\section{引用・参考文献}

［1］小田切徳美「中山間地域の現局面と新たな政策 課題 : 新基本法・直接支払政策導入下に扣いて」 『農林業問題研究』35 巻 4 号 (2000), pp. 209214

[2] 小田切徳美「中山間地域の地域づくり一過疎・ 自立・対策」『北陸の視座』vol. 22（2009）, http://www2.hokurikutei.or.jp/lib/shiza/shiza09/ vol22/topic2/

[3] 山浦陽一「中山間地域等直接支配制度の運用 にみる地域農業の実態: 第 3 期対策への移行 状況と配分割合変更の背景」『大分大学経済論 集』64 巻 2 号 (2012), pp. 31-51

[4]福与徳文「次期集落協定を見越した土地利用 計画：山形県山辺町作谷沢のケースから」『日 本農業経済学会論文集 2005』（2005）， pp. 7-14

[5] 高岸陽一郎・橋詰 登「中山間地域等直接支 払制度に打敉落協定の統合効果」『日本農 業経済学会論文集 2010』(2010), pp. 260-267

（受理日：2013 年 4 月 12 日） 